\title{
Long-term Persistence of Raphia taedigera Mart. Swamps in Nicaragua ${ }^{1}$
}

\author{
Geraild R. Urquhart ${ }^{2}$ \\ Department of Biology, University of Michigan, Ann Arbor, Michigan 48109-1048, U.S.A.
}

\begin{abstract}
The palm Raphia taedigera Mart. forms vast, monodominant swamps in Central and South America, but very little is known about the ecology and natural history of these ecosystems. Debate surrounds the issue whether $R$. taedigera swamps are early successional stages or mature "climax" communities. This paleoecological analysis of a $1.46-\mathrm{m}$ sediment core from swamps on the Caribbean coast of Nicaragua establishes the abundant presence of $R$. taedigera swamps for at least $2800 \pm 90$ years. $R$. taedigera swamps must be considered persistent communities, warranting further study because of their great extension into Central and South America.
\end{abstract}

\section{RESUMEN}

La palma Raphia taedigera Mart. forma pantanos vastos y monodominates en América Central y América del Sur, pero muy poco se conoce sobre la ecología y historia natural de estos ecosistemas. Un debate existe sobre la etapa ccológica de pantanos de $R$. taedigera. Algunos dicen que los pantanos son etapas tempranas en la serie de vegetación, micntras otros creen que es la etapa madura de la comunidad. Se empleó un analisis paleoecológico de un cilindro de sedimentos de $1,46 \mathrm{~m}$ para establecer la presencia abundante de $R$. taedigera en pantanos en la Costa Caribeña de Nicaragua desde por lo menos de $2800 \pm 90$ años. Pantanos de $R$. taedigera deben estar considerados comunidades persistentes y merecen una examinación más profunda debido a su amplia extensión en América Central y América del Sur.

Key words: Arecaceae; Central America; long-term studies; Nicaragua; paleoecology; palms; palynology; Raphia taedigera Mart.; swamps.

Raphia taedighra Mart. (Arecaceae) palms cover LARGE AREAS of Central and South America, yet litthe is known about their ecological role in tropical swamps. This is due to the inaccessibility and impenetrability of $R$. taedigera swamps, resulting in a paucity of research and complete lack of long term studies. Many authors have suggested that $R$. taedigera swamps are a short-lived, pioneering phase in swamp forest succession (Anderson \& Mori 1967. Myers 1984). Devall and Kiester (1987), however, argued that these swamps represent a climax community, suggesting that long-term monitoring of dicots and palms within the swamps would demonstrate this.

Because such studies pose great difficulties, examining the paleoecological record of a forest is more practical for determining successional changes

1 Received 22 October 1997; revision accepted 28 April 1998.

2 Present address: Smithsonian Tropical Research Institute, Center for Paleoecology, Unit 0948, APO AA 34002-0948, U.S.A.; and Center for Great Lakes and Aquatic Sciences, University of Michigan, Ann Arbor, Michigan 48109-1090, U.S.A.. in these ecosystems. Whereas paleoecological records of vegetation typically deal with long-term issues of climatic change and cover several millennia, shorter records that provide fine-resolution histories of vegetation for a given area are increasingly used to answer ecological questions (Sturludottir \& Turner 1985, Green et al. 1988). A short record of vegetation can provide information about persistence, disturbance, and change within an ecological community.

To test the hypothesis that $R$, taedigera swamps are short-lived, I studied the paleoecological record of a $R$. taedigera swamp in eastern Nicaragua. By looking at the pollen deposition over several centuries, I was able to determine the status of both $R$. taedigera and dicot trees in this swamp. The data demonstrate that $R$. taedigera has been a significant element of the swamp forest for at least $2800 \pm$ $90{ }^{14} \mathrm{C}$ years.

\section{STUDY AREA}

The La Union swamp is located behind the farming cooperative La Union de Caño Negro de Pitry 
on Caño Negro, a blackwater creek on the Caribbean coast of Nicaragua $\left(12^{\circ} 05^{\prime} \mathrm{N}, 83^{\circ} 30^{\prime} \mathrm{W}\right)$. Annual rainfall for the area is $c a 3000 \mathrm{~mm}$, with a pronounced dry season from January to April (INETER 1996). This region was struck by a hurricane in October 1988; this caused severe forest damage to 500,000 ha of tropical forest, including 100,000 ha of swamp forest. Much of the swamp forest in the region burned following the hurricane damage, but the 10-ha patch from which the $\mathrm{La}$ Union $200-\mathrm{m}$ core was taken did not burn. Because the patch is more or less downwind from the $20 \mathrm{~m}$ above sea level ridge on which La Union sits, it probably escaped severe hurricane damage and was not a combustible collection of damaged vegetation when the fires came.

The $\mathrm{La}$ Union swamp is presently dominated by $R$. taedigera, an enormous palm of Neotropical swamps. Tree species include Carapa guianensis Aubl. (Meliaceae), Pterocarpus officinalis Jacq. (Fabaceae), Grias cualiftora L. (Lecithydaceae), Cecropia obtusifolia Bertol. (Moraceae), and some immature Calophyllum brasiliense Cambess. and Symphonia globulifera L. f. (both Clusiaceae). Together, $R$, taedigera and other trees form a closed canopy swamp forest $c a 10 \mathrm{~m}$ above the swamp floor. Herbaceous vegetation is predominantly Spathiphyllum friedrichsthalii Schott (Araceae), with small patches of Montrichardia arborescens Schott, Dieffenbachia sp. (both Araceae), and Cyclanthus bipartatus Poit. (Cyclanthaceae).

The coring site is $200 \mathrm{~m}$ from the border between swamp and upland forest in a flat, undisturbed patch area of swamp mud under a few centimeters of standing water. $R$. taedigera, G. cauliflo$r a$, and $C$. obtusifolia, in respective order, were the most common plants in the immediate vicinity. The water table was just above the saturated peats, producing about $5 \mathrm{~cm}$ of standing water in March 1994. During the wet season (May-December) water level rises between 30 to $50 \mathrm{~cm}$ above the soil surface.

\section{METHODS}

In March 1994, I used a simple piston corer to obtain a $1.46-\mathrm{m}$ core from the sediments that had accumulated in the La Union swamp. I anchored the piston cable to a tree limb above the drilling site to hold the piston fixed at ground level. The core tubing was a $2.5-\mathrm{m}$ section of $50-\mathrm{mm}$ PVC tubing, with the outer edge filed at the bottom end to produce a sharpened drilling face. The piston was constructed from two rubber stoppers fixed on a $10-\mathrm{cm}$ long bolt with a ring welded to the top for cable attachment. I pushed the tubing into the ground manually until it would no longer penetrate the sediments, due to lack of rigidity of the coring tube, sampling a total of $1.46 \mathrm{~m}$ of sediments. From three sites within $10 \mathrm{~m}$ of the coring hole, I also collected and mixed together $1-\mathrm{cm}^{3}$ surface samples (hereafter presented as the sample at $0-\mathrm{cm}$ depth) using a simple pinch method (Rodgers \& Horn 1996). I transported the core intact to the Smithsonian Tropical Research Institute where I opened the core tube by cutting lengthwise along the sides using a router and a long wooden box to guide the rourer and hold the core tube.

I sent the bottom most $5 \mathrm{~cm}$ of sediment (depth 141-146 cm) to Beta Analytic for conventional radiocarbon dating. I found many fragments of $R$. taedigera seeds in the sediments at depths of 68 and $108.5 \mathrm{~cm}$. The fragments are $1-2 \times 5-10$ $\mathrm{mm}$ fingerlike projections that permeate the endocarp of the seed. In recently rotted $R$. taedigera seeds collected in Nicaragua, I have found these to be the only remaining internal structures, and their presence in the cores demonstrates their capabilities for persistence. I prepared the fragments from 108.5-cm depth using a series of acid and base washes and transported them to the Lawrence Livermore National Laboratory Center for AMS (CAMS) for accelerator mass spectrometry (AMS) radiocarbon dating. I calibrated the dates to calendar years B.C. (cal B.C.) using the Oxcal v2.18 calibration program (Ramsey 1995).

I prepared samples for pollen counting from every $8 \mathrm{~cm}$ along the core, beginning with $4-\mathrm{cm}$ depth and proceeding to $140-\mathrm{cm}$ depth, along with the surface sample (included as 0 - $\mathrm{cm}$ depth). Pollen and spores from $0.25 \mathrm{~cm}^{3}$ of sediment were concentrated using standard palynological procedures and mounted in glycerin jelly (Faegri et al. 1989). Lycopodium spore tablets were added for concentration calculations. Each sample was counted to at least 200 grains. Pollen concentrations were calculated using the following formula:

$$
\begin{aligned}
& \text { grains } / \mathrm{cm}^{3} \\
&= {\left[\left(4 \text { samples } / \mathrm{cm}^{3}\right) \cdot(12,500 \text { spores } / \text { sample })\right.} \\
&\times(\text { no. pollen grains counted })] \\
&\div \text { (no. Lycopodium spores counted })
\end{aligned}
$$

Charcoal particles $>5 \mu \mathrm{m}$ were tallied while counting pollen. I prepared the pollen diagram using the spreadsheet, Tilia, and graphics software, Tilia Graph (Grimm 1990). 


\section{RESULTS}

Sediment stratigraphy and Chronology.-The $1.46-\mathrm{m}$ sediment core was of highly organic coarse peat. The peat was without significant additions of clay, showing that there had been little or no horizontal transport of sediment from nearby clay soils of the upland forest. The sediments most likely formed in situ with little horizontal transport. Leaf fragments were evident in addition to the discrete bands of decomposed $R$. taedigera seeds. The bands of $R$. taedigera seed fragments suggest that vertical mixing was also minimal. These characters along with the radiocarbon dating demonstrate the suitability of the core for paleoecological analysis.

Sediments from the bottommost section of the core, 141 to $146-\mathrm{cm}$ depth, yielded a radiocarbon determination of $2800 \pm 90{ }^{14} \mathrm{C}$ years before present (B.P.). The $R$ taedigera seed fragments from 108.5-cm depth were dated directly by AMS to $2040 \pm 60 \mathrm{BP}$ (Table 1). A linear regression on these two points forced through the origin yields an sedimentation rate of $0.052 \mathrm{~cm} / \mathrm{yr}$. The two dates nearly fir a line through the origin. Given the rate of accumulation, sampling at $8-\mathrm{cm}$ intervals provides a span of $c a 160$ years between samples.

Palynology.-Raphia taedigera pollen is a simple monosulcate palm grain, averaging $24.0 \pm 1.6 \times$ $16.9 \pm 1.5 \mu \mathrm{m}$ (Urquhart 1997a). It was found throughout the sediment core, making up 13 to 84 percent of total pollen (Fig. 1). Symphonia globulifera is a mature swamp tree that leaves little pollen even if abundant. The mere presence of its pollen suggests that it was a common swamp element. Campnosperma panamensis is a swamp tree usually restricted to better-drained swamps (Phillips 1995). Ilex, Dalbergia, Malpighiaceae, and Apocynaceae pollens were all present at low levels and may have come from either swamp or upland forest. Cecropia is a common pioneer found in gaps in the swamp, and its pollen can be abundant (Rodgers $\&$ Horn 1996). The low levels of its pollen in the record may have come from within the swamp or from nearby upland forest, whereas the high levels likely indicate a local origin. Orher Urticales were grouped due to extreme difficulties in identifying individual taxa. Poaceae and Cyperaceae pollen can disperse long distances and probably came from other regions. Pinus pollen is also wind dispersed and likely came from Pinus caribaea var. hondurensis Morelet savannas located about $25 \mathrm{~km}$ northeast of the La Union swamp. Fern spores were few despite the presence of ferns as common terrestrial

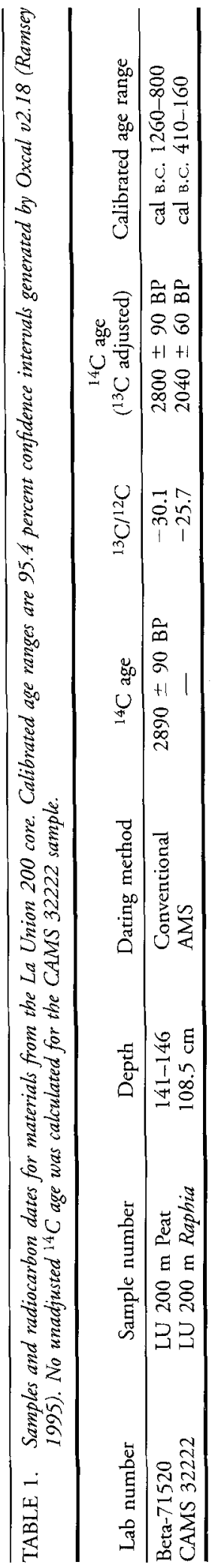




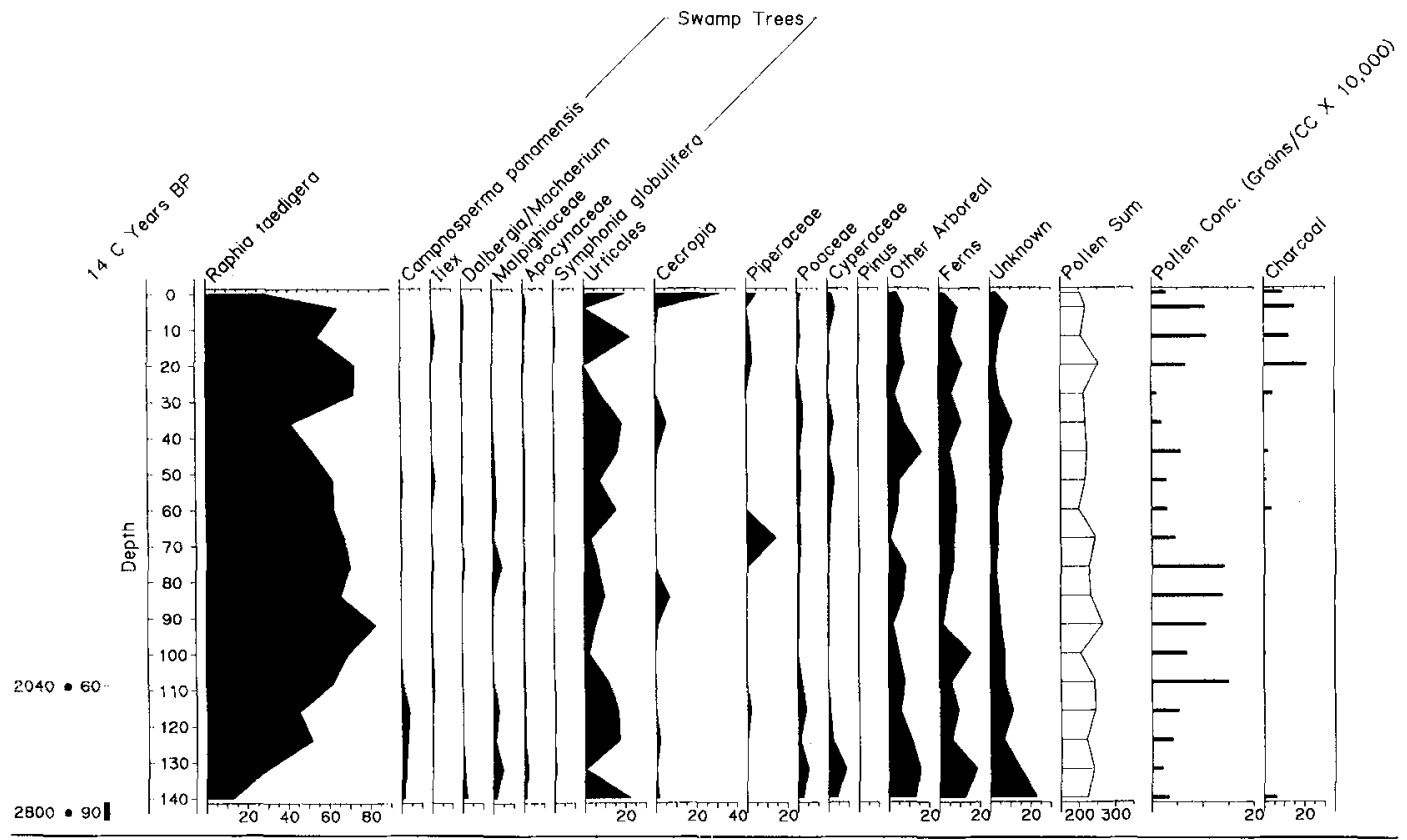

FIGURE 1. Pollen diagram of major pollen and spore types of a 1.46-m sediment core from a Raphia taedigera Mart. (Arecaceae) swamp near Bluefields, Nicaragua. The units for each category are percentage of the pollen sum, except for Pollen Concentration and Pollen Sum.

and epiphytic elements of swamp forests and upland forests. Pollen types in the "other arboreal" grouping were generally tricolporate pollen types that were uncommon and difficult to identify, and may represent further arboreal structure of the forest. Many pollen grains could not be identified due to the high diversity of the vegetation or poor preservation. They are listed as "unknowns" in Figure 1 . The high abundance of $R$. taedigera (from 14 to $>80 \%$ grains per count) made the 200-grain counts sufficient for determining the long-term presence of this species.

\section{DISCUSSION}

The most notable feature of the percentage pollen diagram is the abundance of $R$. taedigera pollen throughout the diagram. Although low at the beginning of the record $(2800 \pm 90$ B.P.), $R$. taedigera increases to become the most common pollen type in the diagram. While abundant pollen is often a signal from a wind-pollinated species, $R$. taedigera is pollinated by beetles (Myers 1984). Pollen in the sediments likely came from fallen flowers dispersed close to their parent plant.

Campnosperma panamensis declined in abundance at the beginning of the pollen diagram and was not found in recent sediments. This paleoecological trend has been observed in a nearby swamp area as well (Urquhart 1997b). Phillips (1995) noted that $C$. panamensis forests were found only in the relatively elevated regions of the swamps, suggesting that it is not tolerant of deeper swamp waters. The decline in C. panamensis pollen may be the result of increased water levels in the swamps. $R$. taedigera is quite tolerant of standing water and flooding (Urquhart 1997b; E. Webb, pers. comm.), and its increase in abundance may have been caused by water depth that excluded other species.

Cecropia pollen increases greatly to 32 percent of total pollen in the surface sample $(0 \mathrm{~cm})$; however, its abundance is quite trivial in the $4-\mathrm{cm}$ depth sample, which can be estimated to represent ca 80 years B.P. It is a rapidly growing pioneer common in light gaps. The modern presence of Cecropia may be the result of hurricane damage that created openings five years before the sampling. The increase of charcoal fragments in the sediments during recent centuries is probably a signal produced by post-Columbian settlements near Bluefields or along Caño Negro.

Although several tree species are found in swamps, they did not outcompete the shotter Raphia palms as might be expected. Many of these 
swamp species have difficulties colonizing swamps with standing water, whereas $R$. taedigera germinates best under submerged conditions (Urquhart 1997b). Additionally, in Costa Rica, the swamps with the most standing water are those dominated by $R$. taedigera (E. Webb, pers. comm.). The exceptional ability of $R$. taedigera to tolerate standing water likely helped it sustain dominance of the swamps studied here.

The persistence of $R$. taedigera pollen throughout the $2800 \pm 90$ year span of this record suggests that $R$. taedigera in swamps form long-lasting ecological communities. The high percentages of its pollen in the core are in the range of percentages in pollen rain from modern $R$. taedigera-dominated forests (Urquhart, pers. obs.) and illustrate that $R$. taedigera was a significant part of the forest ecosystem throughout this time.

\section{ACKNOWLEDGMENTS}

This work was supported by the U.S. Department of Energy Graduate Fellowships for Global Change program and funding from the Rackham Graduate School at the University of Michigan. The facilities provided by P. Colinvaux and the Smithsonian Tropical Research Institute were invaluable. I. Perfecto, B. Rathcke, J. Vandermeer, and $\mathrm{E}$. Werner provided valuable comments on the manuscript. P. Berry, M. Bush, and S. Horn reviewed and edited the manuscript for publication.

\section{LITERATURE CITED}

Aniderson, R., AND S. Mori, 1967. A preliminary investigation of Raphia palm swamps, Puerto Viejo, Costa Rica. Turrialba 17: 221-224.

Devall, M., and R. Kiester. 1987. Notes on Raphia at Corcovado. Brenesia 28: 89-96.

Fai:gri, K., P. E. Kai.and, and K. Krzywinskı. 1989. Textbook of pollen analysis, 4th edition. John Wiley $\&$ Sons, New York, New York.

Green, D., G. Singh, H. Polach, D. Moss, J. Banks, and E. A. Geissilir. 1988. A fine-resolution paleoecology and paleoclimatology from south-eastern Australia. J. Ecol. 76: 790-806.

Grimm, E. C. 1990. Tilia and Tilia Graph: PC spreadsheet and graphics software for pollen data. INQUA-Comission for the study of the Holocene, Working Group on Data-Handling Methods, Newsletter 4: 5-10.

INETER. 1996. Atlas escolar de Nicaragua, 2nd edition. Instituto Nicaragüense de Estudios Territoriales (INETER), Managua, Nicaragua. 31 pp.

MYrRs, R. L. 1984. Growth form, growth characteristics, and phenology of Raphia taedigera in Costa Rican paim swamps. Principes 28: 64-72.

Phil...pS, S. 1995. Holocene evolution of the Changuinola Peat Deposit, Panama: sedimentology of a marine-influenced tropical peat deposit on a tectonically active coast. Ph.D. Dissertation, University of British Columbia, British Columbia, Canada.

Ramsey, C. B. 1995. Oxcal v2.18: Radiocarbon calibration and statistical analysis program. Research Lab for Archaeology, Oxford, England.

Romgers, J. C., and S. P. Horn. 1996. Modern pollen spectra from Costa Rica. Paleogeogr. Paleoclimatol. Paleoecol. 124: 53-71.

Sturludottir, S. A., and J. Turner. 1985. The elm decline at Pawlaw Mire: an anthropogenic interpretation. New Phytol. 99: 323-329.

Urquhart, G. R, 1997a. Paleoecological evidence of Raphia in the pre-Columbian Neotropics. J. Trop. Ecol. 13: $782-792$.

1997b. Disturbance and regeneration of swamp forests in Nicaragua: Evidence from ecology and paleoecology. Ph.D. Dissertation, University of Michigan, Ann Arbor, Michigan. 